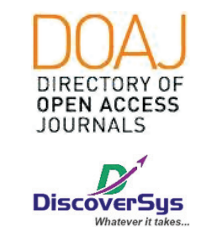

Published by DiscoverSys

\section{The characteristics of neonatal sepsis in Low Birth Weight (LBW) infants at Sanglah General Hospital, Bali, Indonesia in 2018}

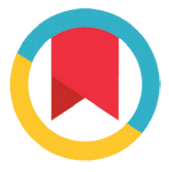

CrossMark

\author{
Ni Luh Gede Wahyuni Suismaya, I Wayan Dharma Artana
}

\title{
ABSTRACT
}

Background: Sepsis is one of the most common causes of mortality and long terms morbidity among infants. It is known to be related to Low Birth Weight (LBW) due to the lack of immunity function to resist the infection. This study aims to identify the characteristics of neonatal sepsis in LBW infants in Sanglah General Hospital.

Method: A retrospective cross-sectional study was conducted in the Neonatal Care Unit, Sanglah General Hospital, during JanuaryDecember 2018 period among 135 neonates. Samples were taken using total sampling for neonates who had LBW and diagnosed with sepsis. Uncompleted data and voluntarily discharge patients were excluded from the study. Data regarding baseline characteristics of respondents, major and minor risk factors, laboratory results of sepsis, as well as blood culture, were analyzed using SPSS version 23 for Windows.
Result: Most of respondents were male (54.1\%), followed by bodyweight 1,500-2,499 grams (58.5\%), and preterm labor ( $<32$ weeks) (86.7\%). The average length of stay was $21.30 \pm$ 19.28 days. The vast majority of infants diagnosed as Early Onset Sepsis (EONS) (89.6\%). Most of the patients had normal leukocyte count (93.3\%), neutrophilia (95.6\%), low I/T ratio (70.4\%), normal platelets (67.4\%), and high procalcitonin (98.5\%). The blood culture showed the most microorganism was Enterococcus faecalis (6.00\%) in grampositive bacteria.

Conclusion: This study found that most of the respondents were male, followed by preterm labor, EONS, normal leukocyte count, low I/T ratio, high procalcitonin, as well as Enterococcus faecalis as the most common gram-positive bacteria.
Child Health Department, Faculty of Medicine, Universitas Udayana, Sanglah General Hospital, Bali, Indonesia
${ }^{*}$ Correspondence to: Ni Luh Gede Wahyuni; Child Health Department, Faculty of Medicine, Universitas Udayana, Sanglah General Hospital, Bali, Indonesia; niluhgedewahyuni69@yahoo.com

Received: 2019-10-08 Accepted: 2020-06-03 Published: 2020-08-01
Keywords: Characteristics, Neonatal Sepsis, Low Birth Weight

Cite This Article: Suismaya, N.L.G.W., Artana, I.W.D. 2020. The characteristics of neonatal sepsis in Low Birth Weight (LBW) infants at Sanglah General Hospital, Bali, Indonesia in 2018. Intisari Sains Medis 11(2): 669-674. D0l: 10.15562/ism.v11i2.639

\section{INTRODUCTION}

LBW is considered as one of the risk factors of infection that occurred among infants. ${ }^{1}$ LBW is defined by babies weighing less than 2,500 grams at birth according to gestational age. ${ }^{1}$ World Health Organization (WHO) classifies LBW into 3 categories; low birth weight babies (LBW) with the weight less than 2500 grams, Very Low Birth Weight (VLBW) is less than 1500 grams, and very low birth weight (VVLBW), who has a weight less than 1000 grams. ${ }^{2}$ It is known that the prevalence of LBW in the USA is $1.46 \%$, with more than $50 \%$ of cases related to death and disability. ${ }^{3}$ According to Indonesian's Ministry of Health, there were $10.20 \%$ of babies (0-59 months) who had LBW with the highest percentage was $16.8 \%$ in Central Celebes. Meanwhile, the lowest was $7.2 \%$ in North Sumatra. ${ }^{4}$ In Bali, it is estimated that the percentage of LBW in 2013 was $9 \%{ }^{4}$

Preterm Infants are well acquaintance to have a higher risk of developing sepsis, and other sequelae compare to term infants. It is suggested that twothirds of LBW in developing countries are premature infants. ${ }^{2}$ Neonatal sepsis is one of the most dangerous systemic infection manifestations, which is defined as a clinical syndrome of systemic infection with bacteremia in the first month of life. ${ }^{3,5}$ In the United States, the data shows that the incidence of early-onset sepsis in VLBW infants was $1.5 \%$, whereas $25 \%$ of late-onset sepsis. ${ }^{6}$ The incidence of neonatal sepsis ranges from 1 to 10 cases per 1000 live births and 1 per live birth monthly. ${ }^{6}$ Following Fundamental Health Research data from the Indonesian Ministry of Health (RISKESDAS) in 2007, it was showed that sepsis is a risk factor for neonatal deaths at the age of $0-6$ days by $12 \%$ and approximately around $20.5 \%$ of neonatal mortality at the age of 7-28 days. ${ }^{7}$ Another data in 2010 showed that the incidence rates of neonatal sepsis in referral hospitals in Indonesia are estimated around $1.5 \%-3.72 \%$ with the considerable high mortality rates which are around $37.09 \%-80 \%{ }^{4,7}$

Several conditions have been identified as risk factors for sepsis. ${ }^{8}$ These conditions include maternal risk factors, such as premature rupture of membranes (especially more than 18 hours), infection and fever during pregnancy, foul-smelling and or meconium-stained liquor, and multiple pregnancies. ${ }^{8}$ Furthermore, there are also risk factors 
for infants, such as prematurity, LBWR, asphyxia, resuscitation during labor, invasive procedures, congenital abnormalities, parenteral nutrition, and also the length of stay in neonates intensive care unit. ${ }^{8}$ Other risk factors include male gender, black race, and low socioeconomic status. ${ }^{8,9}$ Sepsis is triggered by the microorganism that initiated inflammation cascade, beginning with the release of several inflammation mediators. ${ }^{10}$ Naturally, the body will resist the reaction through both the cellular and humoral immune system, including monocytes, macrophages, and neutrophils, antibodies formation and complement pathway activation. ${ }^{10,11}$ Newborns are well acquaintance to have a weaker ability in responding to the infections due to immature immune systems. Low birth weight babies are 2.7 times more likely to develop sepsis due to humoral and cellular immune systems deficiency, and the invasive procedures performed. ${ }^{10,11}$

Clinical manifestations of infection in newborns are varied, with mild to severe manifestations of focal or systemic infections and congenital syndromes, rarely it can also occur from intrauterine infections. ${ }^{12}$ Exposure time, inoculum size, immune status, and virulence of the causative agent influence the manifestations of the disease. The least the specific symptoms associated with sepsis and the limitations of laboratory criteria are causing the diagnosis of sepsis among the newborns is challenging to establish. ${ }^{12}$ Preterm infants and LBW have experienced a significant improvement in their condition, along with the advancement of medical management for them. Nonetheless, long term treatment in the hospital possibly causes the continued risk of getting an infection.

Based on those mentioned above, this study aims to determine the characteristics of neonatal sepsis in LBW in the neonatology room at Sanglah General Hospital, Bali, Indonesia, in 2018.

\section{METHOD}

This study was using a descriptive retrospective design with a cross-sectional approach among subjects who were treated in Sanglah General Hospital's neonatal care unit level 2 and 3. This research was held in August 2019, using data that were collected from LBW infants' medical records who also diagnosed with sepsis registered from January 2018 until December 2018. Uncompleted medical records and patients who voluntarily discharged from the hospital were excluded from the study. The sampling technique that was used in this study is a total sampling method.

The variable in this study includes sex, location of delivery, mode of delivery, birth weight, gestational age, parity, length of stay, neonatal sepsis, outcome, an infection risk factor for neonatal sepsis, infection biomarker. Sepsis is classified as early-onset ( $<72$ hours) and late-onset ( $>72$ hours). The risk factor of sepsis includes mayor and minor risk factors, where the mayor consisted of premature rupture of the membrane more than 24 hours, fever during pregnancy $\left(>38^{\circ} \mathrm{C}\right)$, chorioamnionitis, fetal heartbeat more than 160 times per minute, foul-smelling and or meconium-stained liquor. The minor factor consisted of premature rupture of membranes $>12$ hours, maternal fever at intrapartum (temperature $\geq 37.5^{\circ} \mathrm{C}$ ), low APGAR score (minutes $1<5$, minutes $5<7$ ), VLBW, $<37$ weeks gestation, multiple pregnancies, vaginal discharge, a mother with urinary tract infection (UTI). Infection biomarkers include procalcitonin, leukocyte, neutrophil, I/T ratio, and blood smear. Infection markers leading to sepsis are leukocytosis $\left(>34.000 \times 10^{3} / \mu \mathrm{L}\right)$, leukopenia $\left(<5 \times 10^{3} /\right.$ $\mu \mathrm{L}$ ), neutropenia $<1.5 \mathrm{~K} / \mu \mathrm{L}$, thrombocytopenia $(<150.000 / \mu \mathrm{L})$, procalcitonin $\geq 0,05 \mathrm{ng} / \mathrm{mL}$, IT ratio $>0.2$ and also vacuolization and toxic granule that can be seen from blood smear examination. ${ }^{12}$

Data then analyzed by SPSS 23.0 software. The result will be presented in a descriptive form by a table and narrative explanation. Numerical data with normal distribution were introduced in the median form (minimum-maximum), and data with abnormal distribution are presented in mean form (standard deviation).

\section{RESULT}

A total of 135 infants who were registered from January-December 2018 and also fulfilled the inclusion and exclusion criteria were enrolled in this study. General characteristics of the data can be seen in Table 1. Subjects were dominated by males (54.10\%), born at Sanglah Hospital $(62.20 \%)$ by spontaneous birth (51.90\%). Most of them weigh 1,500-2,499 grams; in addition, there were $13.30 \%$ of them who have birthweight less than 1,000 grams. There were around $86.70 \%$ of infants born preterm. Approximately $9.60 \%$ of them were born before 28 weeks of gestation (Table 1).

The mean length of stay was $21.30 \pm 19.28$ days. The vast majority of infants diagnosed as earlyonset sepsis (EONS) (89.6\%), whereas the other $10.3 \%$ diagnosed as late-onset sepsis (LONS). The mortality percentage of this study was $35.6 \%$ (Table 1).

The risk factors of infection can be seen in Table 2. From the mayor factors, premature rupture of the membrane (PRM) more than 24 hours was the most common factor found among the subjects (11.9\%) followed by fetal distress $(9.6 \%)$ and foulsmelling and or meconium-stained liquor (8.9\%). 
Table 1 Baseline characteristics of respondents

\begin{tabular}{|c|c|}
\hline Variables & Respondents $(\mathrm{N}=135)$ \\
\hline \multicolumn{2}{|l|}{ Sex, n (\%) } \\
\hline Male & $73(54.1)$ \\
\hline Female & $62(45.9)$ \\
\hline \multicolumn{2}{|l|}{ Location of Delivery, n (\%) } \\
\hline Sanglah General Hospital & $84(62.2)$ \\
\hline Referral & $51(37.8)$ \\
\hline \multicolumn{2}{|l|}{ Mode of delivery, $\mathbf{n}(\%)$} \\
\hline Spontaneous & $70(51.9)$ \\
\hline Forceps extraction & $3(2.2)$ \\
\hline Vacuum extraction & $0(0)$ \\
\hline Caesarian section & $62(45.9)$ \\
\hline \multicolumn{2}{|l|}{ Birthweight (Gram), n (\%) } \\
\hline$<1,000$ & $18(13.3)$ \\
\hline $1,000-1,499$ & $38(28.1)$ \\
\hline $1,500-2,499$ & $79(58.5)$ \\
\hline \multicolumn{2}{|l|}{ Gestational age (Weeks), n (\%) } \\
\hline$<28$ & $13(9.6)$ \\
\hline $28-31$ & $41(30.4)$ \\
\hline $32-36$ & $63(46.7)$ \\
\hline 37 & $18(13.3)$ \\
\hline \multicolumn{2}{|l|}{ Number of Parity, n (\%) } \\
\hline 1 & $75(55.6)$ \\
\hline 2 & $36(26.7)$ \\
\hline$>3$ & $24(17.7)$ \\
\hline Length of stay (Days) (Mean \pm SD) & $21.30(19.28)$ \\
\hline \multicolumn{2}{|l|}{ Sepsis } \\
\hline EONS & $121(89.60)$ \\
\hline LONS & $14(10.40)$ \\
\hline \multicolumn{2}{|l|}{ Outcome, n (\%) } \\
\hline Survive & $87(64.4)$ \\
\hline Death & $48(35.6)$ \\
\hline
\end{tabular}

From minor risk factors, the most common was preterm, with the percentage of $68.1 \%$ followed by asphyxia (41.5\%) and very low birth weight (37.8\%) (Table 2).

Infection markers that were used in this study were leukocyte, neutrophil, IT ratio, platelets, procalcitonin, and peripheral blood smear. Most of the patients (93.3\%) had leukocyte count around $5-34 \mathrm{~K} / \mu \mathrm{L}$, neutrophils $>1.5 \mathrm{~K} / \mu \mathrm{L}(95.6 \%), \mathrm{I} / \mathrm{T}$ ratio $<0.2(70.4 \%)$, platelets $>150 \mathrm{~K} / \mu \mathrm{L}(67.4 \%)$, and procalcitonin $>0.05 \mathrm{ng} / \mathrm{ml}(98.5 \%)$. From the peripheral blood smears, it can be seen that there were $11.1 \%$ of subjects with vacuolization and $6.7 \%$ with toxic granule. Complete data can be seen in Table 3 .
The etiology of infection was seen by using blood culture. Table 4 is showing the result of blood culture that was performed on the subjects. The most common bacteria that can be seen was Enterococcus faecalis (6\%), followed by Staphylococcus cohnii (4.7\%) and Staphylococcus haemolyticus (3.5\%) as gram-positive bacteria. Most of the subjects (71.8\%) had a sterile blood culture (Table 4).

\section{DISCUSSION}

From the general characteristics of the subjects, it is found that the majority of the subjects were male, born in Sanglah Hospital by spontaneous delivery, weighing 1500-2499 grams, preterm, and null parity. These results are almost familiar with the study conducted by Utomo in 2010 , where $61 \%$ of the LBW infants with sepsis were male, $44 \%$ born by spontaneous delivery, $72 \%$ weighing 1500 2499 grams, and $78 \%$ preterm. ${ }^{1}$ The predominance of male infants in this study possibly caused by a sexlinked factor in the $\mathrm{X}$ chromosome. ${ }^{13}$ The gene that is involved in the synthesis immunoglobulin inside the $\mathrm{X}$ chromosome has been postulated as a reason behind male predominance, even though most of the study did not show any significantly different in the percentage of male and female infants. ${ }^{13}$

Most of them were diagnosed as early-onset sepsis (EONS). This result is different from a study conducted by Lim WH et al. in China that showed 93.7\% of subjects were accounted for as late-onset sepsis. ${ }^{14}$ Another study from North Carolina showed that the vast majority of subjects, which were 12.204 infants from 108.000 participants were diagnosed with LONS. ${ }^{6}$ In contrast, another 1032 infants were diagnosed with EONS. ${ }^{6}$ Another study suggested that risk factors for EONS include lower gestational age, female sex, lower APGAR, exposure of antenatal antibiotics, the need for mechanical ventilation on the first day of life and outborn status, whereas for LONS are lower gestational age and exposure to antibitocs. ${ }^{15}$ In this study, beside of prematurity, asphyxia which contributes to the APGAR score also have a higher percentage that could be correlated with a higher percentage of EONS in this study.

The mortality percentage of this study was $35.6 \%$. This number is relatively lower than the mortality percentage in Dr. Soetomo General Hospital, where $69.0 \%$ of LBW infants with sepsis died during the study. ${ }^{1} \mathrm{~A}$ study conducted in China showed that the case fatality rate of sepsis among VLBW was $7 \%$, which is much lower than this study result. ${ }^{14}$ Notwithstanding, they mentioned that infants with early-onset sepsis had a much higher fatality rate than late-onset $(40 \%$ vs. $5 \% ; \mathrm{p}<0.01){ }^{14}$ This could be a possible explanation about high mortality 
Table 2 Infection Risk Factors for Neonatal Sepsis

\begin{tabular}{lc}
\hline Variables & Respondents (N=135) \\
\hline Major risk factors, $\mathbf{n}(\%)$ & $16(11.90)$ \\
PRM $>24$ hours & $3(2.20)$ \\
Maternal fever $>38^{\circ} \mathrm{C}$ & $0(0.00)$ \\
Chorioamnionitis & $13(9.60)$ \\
Fetal distress & $12(8.90)$ \\
Foul-smelling and or meconium-stained liquor & \\
Minor risk factors, $\mathbf{n}(\%)$ & $13(9.60)$ \\
PRM $>12$ hours & $6(4.40)$ \\
Maternal fever $>37,5^{\circ} \mathrm{C}$ & $56(41.50)$ \\
Asphyxia & $51(37.80)$ \\
VLBW & $92(68.10)$ \\
Gestational age $<37$ weeks & $9(6.70)$ \\
Multiple gestations & $24(17.80)$ \\
Maternal vaginal discharge & $7(5.20)$ \\
Maternal urinary tract infection & \\
\hline
\end{tabular}

Table 3 Laboratory Evaluation of Sepsis in Low Birth Weight (LBW) Infants

\begin{tabular}{|c|c|}
\hline Laboratorium Parameter & n (\%) \\
\hline \multicolumn{2}{|l|}{ Leukocyte, n (\%) } \\
\hline$<5 \mathrm{~K} / \mu \mathrm{L}$ & $4(3.00)$ \\
\hline $5-34 \mathrm{~K} / \mu \mathrm{L}$ & $126(93.30)$ \\
\hline$>34 \mathrm{~K} / \mu \mathrm{L}$ & $5(3.70)$ \\
\hline Leukocyte counts $(\mathrm{K} / \mu \mathrm{L})($ Mean $\pm \mathrm{SD})$ & $13.88 \pm 7.86$ \\
\hline \multicolumn{2}{|l|}{ Neutrophils, n (\%) } \\
\hline$<1.5 \mathrm{~K} / \mu \mathrm{L}$ & $6(4.40)$ \\
\hline$\geq 1.5 \mathrm{~K} / \mu \mathrm{L}$ & $129(95.60)$ \\
\hline Neutrophil $(K / \mu L)($ Mean $\pm S D)$ & $6.87 \pm 6.66$ \\
\hline \multicolumn{2}{|l|}{ IT Ratio, n (\%) } \\
\hline$<0.2$ & $95(70.40)$ \\
\hline$>0.2$ & $40(29.60)$ \\
\hline IT ratio (median (min-max)) & $0.18(0.01-0.73)$ \\
\hline \multicolumn{2}{|l|}{ Platelets, n (\%) } \\
\hline$<150 \mathrm{~K} / \mu \mathrm{L}$ & $44(32.60)$ \\
\hline$\geq 150 \mathrm{~K} / \mu \mathrm{L}$ & $91(67.40)$ \\
\hline Platelets $(\mathrm{K} / \mu \mathrm{L})($ median $(\min -\max ))$ & $186.2(6.84-521.70)$ \\
\hline \multicolumn{2}{|l|}{ Procalcitonin, n (\%) } \\
\hline$<0.05 \mathrm{ng} / \mathrm{mL}$ & $2(1.50)$ \\
\hline$\geq 0.05 \mathrm{ng} / \mathrm{mL}$ & $133(98.50)$ \\
\hline Procalcitonin $(\mathrm{ng} / \mathrm{dL})($ Mean $\pm \mathrm{SD})$ & $5.11 \pm 21.80$ \\
\hline \multicolumn{2}{|l|}{ Peripheral blood smear, n (\%) } \\
\hline Vacuolization & $15(11.10)$ \\
\hline Toxic granule & $9(6.70)$ \\
\hline
\end{tabular}

in this study regarding the domination of EONS cases in this study. Another study also supported that statement where they found that LBW infants who diagnosed with EONS were 1.45 times more likely to be death whereas the risk for LONS was 1.30 times higher in infants. ${ }^{6}$

From the mayor factors, the most common risk factors found were premature rupture of the membrane (PRM) more than 24 hours, fetal distress and foul-smelling, and or meconium-stained liquor. Meanwhile, preterm, asphyxia, and very low birth weight were the top three from minor factors. This result was similar to the literature before. The two most important risk factors for sepsis are premature, especially birth before 31 weeks $(\mathrm{OR}=3.9$; 95\% CI $=1.4-11.0)$ and birth weight less than 1500 grams $(\mathrm{OR}=5.7 ; 95 \% \mathrm{CI}=2.5-15.6) .{ }^{15}$ Another study suggested that the risk of infection among preterm infants is 11 times higher because of barriers immaturity and incomplete developed immune system. ${ }^{16}$ It is believed that preterm infants have immunoglobulin and complement system deficiencies, as well as a lack of opsonization and phagocytosis response by the immune system. ${ }^{16}$ The primary factor, premature rupture of the membranes, is known to comorbid 3.0-4.5\% of pregnancy but associated with $40 \%$ preterm deliveries. This can give an indirect association with sepsis incidence among low birth weight infants. ${ }^{17}$

Infection markers leading to sepsis are leukocytosis $\left(>34.000 \times 10^{3} / \mu \mathrm{L}\right)$, leukopenia $(<5 \times$ $10^{3} / \mu \mathrm{L}$ ), neutropenia $<1.5 \mathrm{~K} / \mu \mathrm{L}$, thrombocytopenia $(<150.000 / \mu \mathrm{L})$, procalcitonin $\geq 0.05 \mathrm{ng} / \mathrm{mL}$, IT ratio $>0.2$ and also vacuolization and toxic granule that can be seen from blood smear examination. All those markers are representative of inflammation reactions that occur during infection and sepsis. ${ }^{18}$ However, in this study, it is found that most of the patients had a normal leukocyte count, neutrophilia, low I/T ratio, normal thrombocyte count, and high procalcitonin. Some literature stated that the normal count of leukocyte is often seen during the initial infection phase among infants, and it will eventually become normal after 12 hours of onset. The sensitivity of leukocytosis is $17 \%-90 \%$, with $31 \%-100 \%$ specificity. ${ }^{15}$ Normal count in this study perhaps caused by the timing of sample collection. Another study also found that there is an association for normal and low leukocyte count with EONS. ${ }^{19}$ This makes perfect sense since the majority of subjects in this study were diagnosed with EONS. Immature to Total neutrophils $(\mathrm{I} / \mathrm{T})$ ratio more than 0.2 has a low positive predictive value (PPV) (23.0\%) but a high negative predictive value (NVP) (92.0\%). This fact may be explained the lower value of the $\mathrm{I} / \mathrm{T}$ ratio in 
Table 4 The Result of Blood Culture

\begin{tabular}{lc}
\hline Microorganism & $\mathbf{n}(\%)$ \\
\hline Gram-positive bacteria & \\
Enterococcus faecalis & $10(6.00)$ \\
Staphylococcus cohnii & $8(4.70)$ \\
Staphylococcus haemolyticus & $6(3.50)$ \\
Staphylococcus kloosin & $4(2.40)$ \\
Staphylococcus epidermidis & $2(1.20)$ \\
Staphylococcus coagulase-negative & $1(0.60)$ \\
Gram-negative bacteria & \\
Pseudomonas aeroginosa & $2(1.20)$ \\
Klebsiella pneumonia & $2(1.20)$ \\
Acinetobacter baumannii & $1(0.60)$ \\
Stenotrophomonas maltophilia & $1(0.60)$ \\
Stephanoascus ciferrii & $1(0.60)$ \\
Sterile & $97(71.80)$ \\
\hline
\end{tabular}

this study. Nonetheless, if the I/T ratio is combined with thrombocytopenia, the PPV will increase to $43 \%$ and NVP $96 \%{ }^{15}$ A study conducted by Hornik et al. found that high I/T ratio ad low neutrophils count are associated with increased risk of sepsis among neonates $(\mathrm{OR}=5.3$ and 7.39, respectively). ${ }^{19}$ Normal thrombocyte count in this study can be caused by the dominancy of EONS among subjects. Hornik et al. stated that platelet count does not look helpful as sepsis biomarkers in the setting of EONS due to a small increase in odds of sepsis with thrombocytopenia. ${ }^{19}$ In this study, the result of procalcitonin was similar to the other previous studies, wherein neonatal sepsis, the level of procalcitonin, tends to be increased. A study from de Rueda Salguero et al. found that the sensitivity of procalcitonin in predicting sepsis is $100 \%$ with $95.2 \%$ specificity. ${ }^{20}$

There were only a few subjects who were found to had vacuolization and toxic granule in their peripheral blood smears. Vacuolization and toxic granules are the manifestations of degenerative changes in neutrophils. ${ }^{21}$ As sepsis occurring in the body, neutrophils will increase in number and also change in morphologic in order to fight the infection. ${ }^{21}$ A study shows that $60 \%$ of infants who had toxic granules and $11 \%$ vacuolization were very likely to develop sepsis. ${ }^{15}$ It is believed that continues stimulation of neutrophils production and increment of neutrophils maturation in bone marrow also plays a significant role in the making of degenerative changes among neutrophils cells. However, most of the infants have not had a fully developed granulopoietic system yet. ${ }^{22}$ That fact could be an answer to the low percentage of sepsis neonates who had vacuolization and toxic granule in this study.

The most common pathogen was gram-positive bacteria. It is similar to the result of Utomo's study that found $100 \%$ of the blood culture with bacterial growth showed gram-positive bacteria. ${ }^{1}$ A study conducted by Lim et al. also showed similar results where gram-positive bacteria caused $60.7 \%$ of neonatal sepsis, mostly coagulase-negative staphylococcus/CoNS (52.5\%). ${ }^{14}$ However, many studies show that CoNS infection more likely to be related to LONS instead of EONS. ${ }^{14,15}$ The most common causes of EONS were gram-negative bacteria (58.2\%), followed by gram-positive (34.4\%) and Candida Sp (2.7\%) whereas, 61.4\% LONS cases were caused by gram-positive bacteria especially CONS followed by gram-negative $(26.2 \%)$ and Candida (10.5\%). ${ }^{15}$ In this study, even though the culture results show gram-positive predominance, the vast majority of subjects diagnosed as EONS. The explanation about that has not been understood yet.

This study has several limitations. This study uses a retrospective descriptive method so that it cannot assess the significance of the results of the study. The study also did not identify patterns of antibiotic sensitivity and resistance, which could also play a role in the outcome of neonatal sepsis. The infection markers listed in this study are when the subject is admitted to the hospital. At the same time, the time is not necessarily the beginning of the appearance of symptoms considering that most of the subjects are referral cases that have been treated in other hospitals that may be in therapy so that the marker of infection cannot real sepsis condition.

\section{CONCLUSION}

The recent findings conclude that the characteristics of neonatal sepsis in Low Birth Weight (LBW) infants at Sanglah General Hospital, Bali were dominated by male, spontaneous delivery, 1,5002,499 grams of bodyweight, 32-36 weeks of gestational age, and Early Onset Sepsis (EONS). Besides, based on the risk of infection, PRM $>24$ hours was predominant in major risk factors and gestational age $<37$ weeks for minor risk factors for sepsis. The leukocyte count of $5-34 \mathrm{~K} / \mu \mathrm{L}$ was dominant in this study. Besides, based on the type of microorganism, Enterococcus faecalis was the most frequent in gram-positive bacteria and Pseudomonas aeruginosa, as well as Klebsiella pneumonia in gramnegative bacteria. 


\section{CONFLICT OF INTEREST}

There was no conflict of interest in this study.

\section{ETHICS CONSIDERATION}

Ethical clearance of this study was given by Bidang Penelitian dan Pengembangan (Litbang) Komisi Etika Penelitian Fakultas Kedokteran Universitas Udayana RSUP Sanglah Denpasar No: 2485/ UN.14.2.2.VII.14/LP/2019.

\section{FUNDING}

This study was self-funding.

\section{AUTHOR CONTRIBUTION}

All of the authors are equally contributed to the study from the conceptual framework, data gathering, data analysis until reporting the results of study through publication.

\section{REFERENCES}

1. Utomo MT. Neonatal Sepsis in Low Birth Weight Infants in Dr. Soetomo General Hospital. Indonesian Journal of Tropical and Infectious Disease. 2010;1(2):86-89.

2. United Nations Children's Fund and World Health Organization. Low birthweight country, regional and global estimates. Switzerland: The United Nations Children's Fund and World Health Organization. 2004: p.1-27.

3. Goldenberg RL, Culhane JF. Low birth weight in the United States. Am J Clin Nutr. 2007;85(2):584S-590S

4. Mahumud RA, Sultana M, Sarker AR. Distribution and Determinants of Low Birth Weight in Developing Countries. J Prev Med Public Health. 2017;50(1):18-28.

5. Shah BA, Padbury JF. Neonatal sepsis: an old problem with new insights. Virulence. 2014;5(1):170-178.

6. Hornik CP, Fort P, Clark RH, Watt K, Benjamin Jr DK, Manzoni P, et al. Early and late onset sepsis in very-lowbirth-weight infants from a large group of neonatal intensive care units. Early Hum Dev. 2012;88 Suppl 2(Suppl 2): S69-S74.

7. Aminullah A. Sepsis pada bayi baru lahir. Dalam: Kosim M, Yunanto A, Dewi R, Saroso GI, Usman A. Buku Ajar Neonatologi. Edisi 1. Jakarta: Badan Penerbit IDAI. 2008; p. 170-87.

8. Hodgin KE, Moss M. The epidemiology of sepsis. Curr Pharm Des. 2008;14(19):1833-1839.
9. Galiatsatos P, Brigham EP, Pietri J, Littleton K, Hwang S, Grant MC, et al. The effect of community socioeconomic status on sepsis-attributable mortality. J Crit Care. 2018;46:129-133.

10. Short MA. Linking the sepsis triad of inflammation, coagulation, and suppressed fibrinolysis to infants. Adv Neonatal Care. 2004;4(5):258-273.

11. Dharma BDA, Mulyantari NK, Prabawa IPY. Analisis korelasi kadar serum prokalsitonin dengan jumlah leukosit pada penderita dengan kecurigaan sepsis di RSUP Sanglah, Bali, Indonesia. Intisari Sains Medis. 2020;11(1):179-182.

12. Aggarwal R, Sarkar N, Deorari AK, Paul VK. Sepsis in the newborn. Indian J Pediatr. 2001;68(12):1143-1147.

13. Purtilo DT, Sullivan JL. Immunological bases for superior survival of females. Am J Dis Child. 1979;133(12): 1251-1253.

14. Lim WH, Lien R, Huang YC, Chiang MC, Fu RH, Chu SM, et al. Prevalence and pathogen distribution of neonatal sepsis among very-low-birth-weight infants. Pediatr Neonatol. 2012;53(4):228-234.

15. Haque K. Neonatal Sepsis in the Very Low Birth Weight Preterm Infants: Part 2: Review of Definition, Diagnosis and Management. Journal of Medical Sciences. 2010;3(1):11-27.

16. Stoll BJ, Hansen N, Fanaroff AA, Wright LL, Carlo WA, Ehrenkranz RA, et al. Late-onset sepsis in very low birth weight neonates: the experience of the NICHD Neonatal Research Network. Pediatrics. 2002;110(2 Pt 1):285-291.

17. Ashraif M, Haq M, Ashraf W, Ahmed F. Early Onset Neonatal Sepsis in Preterm Premature Rupture of The Membrane. Pak Armed Forces Med J. 2015;65(2):226-230.

18. Makhoul IR, Sujov P, Smolkin T, Lusky A, Reichman B; Israel Neonatal Network. Pathogen-specific early mortality in very low birth weight infants with late-onset sepsis: a national survey. Clin Infect Dis. 2005;40(2):218-224.

19. Hornik CP, Benjamin DK, Becker KC, Benjamin DK, Li J, Clark RH, et al. Use of the complete blood cell count in early-onset neonatal sepsis. Pediatr Infect Dis J. 2012;31(8):799-802.

20. de Rueda Saiguero OODR, Mosquera JN, Gonzalez MB, Crespo MJR, de Soria COL. Cord blood procalcitonin in the assessment of early onset neonatal sepsis. A Pediatr. 2017;87(2):87-94.

21. Peng CT, Lin HC, Wang DW, Tsai CH. Degnerative changes in neutrophils as an indicator of neonatal sepsis. Zhonghua Min Guo Xiao Er Ke Yi Xue Hui Za Zhi. 1989;30(5):309-315.

22. Meirina F, Lubis B, Sembiring T, Siregar O. Hematological scoring system as an early diagnostic tool for neonatal sepsis. Paediatrica Indonesiana. 2015;55(6):315-321.

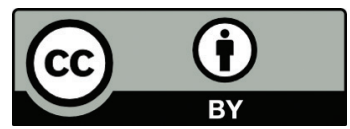

This work is licensed under a Creative Commons Attribution 